\title{
Pengembangan Teknologi Pembangkit Listrik Tenaga Angin Untuk Nelayan Guna Meningkatkan Kapasitas Ikan Tangkapan
}

\author{
M. Iqbal Arsyad ${ }^{1)}$, Fitri Imansyah ${ }^{2)}$, Jannus Marpaung ${ }^{3)}$, Redi Ratiandi ${ }^{3)}$ \\ 1),2),3),4) Jurusan Teknik Elektro, Fakultas Teknik, Universitas Tanjungpura
}

Corresponding Author: M. Iqbal Arsyad, iqbal.arsyad@ee.untan. ac.id

\begin{abstract}
Abstrak: Peningkatan kemampuan dan kemauan masyarakat pesisir pantai untuk meningkatkan muatan iptek dalam usahanya perlu mendapat perhatian serius dari pemerintah dan pihak lain yang berkepentingan dengan pembinaan nelayan. Tugas tersebut memang tidak mudah mengingat masih rendahnya tingkat pendidikan mereka. Perlu juga jadi perhatian bahwa penerapan, pengembangan dan penguasaan iptek perikanan juga menuntut perubahan sikap dari masyarakat umum, khususnya para konsumen produk perikanan. Iptek perikanan sangat diperlukan utamanya untuk mendukung program pembangunan perikanan, termasuk di dalamnya pengelolaan sumber daya perikanan, mendukung terwujudnya jaringan agribisnis dan agroindustri yang tangguh dan berkelanjutan. Pembangunan sistem pembangkit energi listrik yang memanfaatkan sumber daya energi terbarukan, terutama pemanfaatan energi angin banyak diterapkan di daerah pantai, sebagian besar dari pembangunan tersebut berupa proyek-proyek percontohan. Pada dasarnya pembangkit listrik tenaga angin bekerja dengan mengubah energi angin menjadi energi kinetik yang kemudian melalui generator dijadikan energi listrik. Permasalahan kegiatan ini adalah bagaimana merancang komponen-komponen bagian dari kincir angin seperti poros, roda gigi maupun rangka sehingga kincir angin dapat menghasilkan energi listrik sesuai yang diinginkan. Pembangkit listrik tenaga angin ini menggunakan kincir angin sumbu horizontal tipe multiblade 8 sudu. Kincir berputar mengikuti arah datangnya angin menggunakan transmisi dan generator DC. Kapasitas energi listrik yang dihasilkan dari pembangkit listrik tenaga angin ini adalah $300 \mathrm{~W}$ DC, $12 \mathrm{~V}$ pada kecepatan 5 $\mathrm{m} / \mathrm{s}$, dengan sistem penyaluran listrik terkontrol dan proses penyimpanan dalam akumulator. Selanjutnya dari hasil penyimpanan tersebut dapat dimanfaatkan nelayan untuk mencharge accu yang dapat dibawa ke bagan nelayan mereka untuk dapat disambungkan ke lampu.
\end{abstract}

Kata Kunci: Iptek perikanan, energi angin, multiblade 8 sudu.

Abstract: Increasing the ability and willingness of coastal communities to increase the content of science and technology in their business needs serious attention from the government and other parties with an interest in fisherman development. This task is not easy considering their low level of education. It is also necessary to pay attention to the fact that the application, development and mastery of fisheries science and technology also demands a change in the attitude of the general public, especially fishery product consumers. Fishery science and technology is needed primarily to support fishery development programs, including management of fishery resources, to support the creation of a strong and sustainable agribusiness and agro-industry network. The construction of a power generation system that utilizes renewable energy resources, especially the use of wind energy, is widely applied in coastal areas, most of which are in the form of pilot projects. Basically, wind power plants work by converting wind energy into kinetic energy which is then turned into electrical energy through a generator. The problem of this activity is how to design the components of a windmill such as shafts, gears and frames so that the windmill can produce the desired electrical energy. This wind power plant uses an 8-blade multiblade horizontal axis windmill. The mill rotates following the direction of the wind using a DC transmission and generator. The capacity of electrical

Submitted: 22.01.2021, Revised: 06.04.2021, Accepted: 09.04.2021 
energy generated from this wind power plant is $300 \mathrm{~W} \mathrm{DC,} 12 \mathrm{~V}$ at a speed of $5 \mathrm{~m} / \mathrm{s}$, with a controlled electricity distribution system and storage process in an accumulator. Furthermore, from the storage results, fishermen can use it to charge batteries which can be brought to their fishermen's chart to be connected to the lamp.

Keywords: Fishery science and technology, wind energy, multiblade 8 blades.

\section{Pendahuluan}

Keberhasilan pembangunan di segala bidang tidak terlepas dari dukungan dan penerapan ilmu pengetahuan dan teknologi (iptek). Iptek berperan dalam pemberdayaan sumber daya perikanan dalam rangka peningkatan produksi perikanan yang berwawasan lingkungan. Untuk itu diperlukan suatu pendekatan yang integratif dalam pembuatan program menuju pemberdayaan sumber daya perikanan melalui pengembangan ilmu pengetahuan dan teknologi yang mempertimbangkan permintaan industri primer, sekunder dan tersier. Pengembangan ilmu pengetahuan dan teknologi tersebut dapat bersifat novelty (unsur kebaharuan), manajerial (pengembangan dari yang sudah ada termasuk teknologi impor) atau manuver (menarik atau mendorong yang tertinggal) yang didukung kelembagaan yang mantap dan efisien.

Pengembangan ilmu pengetahuan dan teknologi harus pula mempertimbangkan berbagai aspek, seperti aspek hukum dan penegakkannya, aspek sosial, budaya dan ekonomi, sehingga dapat berdaya guna dan berhasil guna bagi kelanjutan pembangunan Indonesia. Untuk itu diperlukan pula adanya keterkaitan dengan berbagai pihak dalam berbagai bentuk seperti adanya suatu network yang terjalin rapi sehingga mendukung tersedianya suatu jaringan informasi perikanan yang akurat dan dapat diandalkan mencakup informasi data daerah (lokasi), data biologi, data teknis, data sosial ekonomi dan data non peternakan. Networking sumber daya dan pembiakan merupakan networking yang perlu segera direalisasikan.

Pembangunan untuk penduduk di pesisir pantai dalam usaha pengembangan perikanan dapat dilakukan dengan penerapan teknologi yang bertujuan untuk (1) mengoptimalkan pemanfaatan sumber daya yang belum tereksploitasi dan rendah tingkat pengusahaannya, (2) mengindentifikasi sumber daya baru, (3) mengurangi "discard mortality", (kematian yang tidak terkendali) (4) mengembangkan dan menggunakan teknik dan alat tangkap yang selektif, ramah lingkungan dan ekonomis.

Iptek di bidang perikanan terus berkembang, sehingga mendukung dan mengarahkan pembangunan sesuai visi pembangunan perikanan, yaitu pembangunan perikanan modern, berbudaya industri dan berbasis pedesaan. Iptek dalam industri perikanan mempunyai dua fungsi, yaitu pertama sebagai dasar untuk menetapkan arah yang harus ditempuh agar industri tersebut tangguh dan kedua sebagai alat untuk aktualisasi suatu potensi, pengembangan produk baru, peningkatan efisiensi produksi dan usaha, pertambahan nilai, pemecahan masalah operasional dan analisis.

Dalam kaitan dengan pengabdian ini, sejalan dengan perkembangan kebutuhan akan energi listrik pada stabilitas sistem merupakan salah satu usaha yang dilakukan untuk meningkatkan kapasitas cadangan listrik dengan harapan agar kontinuitas dan keandalan penyediaan listrik kepada beban semakin meningkat. Sehingga dengan kerja interkoneksi (Switch On-Off) pada sistem accu, daya listrik yang dibutuhkan oleh beban dapat dipenuhi.

Sebagai salah contoh bagaimana suatu peralatan yang dibuat oleh pelaksana dengan melihat kenyataan dari dekat masyarakat pesisir pantai dengan salah satu cara penangkapan 
ikan mengunakan sistem bagan yang dilengkapi perahu kecil serta bambu-bambu dan pancangan (kayu nibong) dengan bantuan lampu petromaks untuk menarik perhatian ikan.

Hal ini juga didasarkan pada kenyataan yang berkembang di masyarakat yaitu tidak adanya sentuhan teknologi untuk peningkatan kapasitas ikan tangkapan. Hal ini berlawanan sekali dengan kebijaksanaan pemerintah dalam hal pengembangan produksi di bidang perikanan laut yang memprioritaskan dan pengikutsertaan masyarakat banyak, serta pengembangan produksi hendaknya tersebar di semua daerah terutama sekali untuk mencapai kelompok perikanan yang maju. Peningkatan produktivitas usaha penangkapan terutama sekali ditujukan pada usaha, antara lain: modernisasi perahu layar, modernisasi bahan dan alat penangkapan dari serat alam menjadi serat sintesis, perubahan jenis alat tangkap ke arah yang lebih produktif, dan pemakaian alat tangkap tambahan disamping alat utama.

Dengan alasan tersebut maka kegiatan pengabdian ini disamping menunjang program pemerintah di bidang perikanan yaitu khususnya peningkatan produktivitas perikanan laut juga memanfaatkan energi alternatif yaitu angin yang dipadukan dengan sumber DC batere dan lampu neon bawah air laut pada bagan nelayan yang bersumber dari energi angin. Kegiatan ini akan merubah atau menggantikan lampu petromaks untuk nelayan bagan menjadi lampu listrik yang sederhana yang dapat dijangkau oleh masyarakat (para nelayan), sehingga diharapkan dalam waktu tertentu dapat meningkatkan baik dari segi jumlah maupun produktivitas masing-masing nelayan bagan, dengan demikian program pemerintah mengenai ikan murah dapat tercapai.

Untuk realisasi peralatan tersebut perlu adanya pemanfaatan kincir angin bagi pembangkitan tenaga listrik skala kecil dan diperlukan sebuah pengatur tegangan, oleh karena kecepatan angin selalu berubah-ubah, sehingga tegangan juga berubah. Untuk itu diperlukan sebuah baterai/accu guna menyimpan energi sementara, jika angin tidak bertiup.

Kincir angin merupakan suatu perangkat yang memanfaatkan energi angin untuk membangkitkan energi listrik. Kincir angin dapat digunakan untuk daerah-daerah pedesaan dan daerah kepulauan yang belum mempunyai mesin pembangkit tenaga listrik dan untuk daerah-daerah yang sulit dijangkau dari pembangkit tenaga listrik. Untuk mendapatkan tenaga dari kincir angin yang sesuai dengan daya yang kita inginkan, maka komponen-komponen dari kincir angin dapat kita rencanakan sebaik mungkin. Misalnya poros, ini harus kita rencanakan sebaik mungkin, misalnya bahan apa yang kita gunakan, berapa kekuatan dari poros itu sendiri. Selain itu kerangka juga harus kita rencanakan, dari bahan apa yang kita gunakan untuk membuatnya.

Kincir angin merupakan sebuah alat yang digunakan dalam Sistem Konversi Energi Angin (SKEA). Kincir angin berfungsi merubah energi kinetik angin menjadi energi mekanik berupa putaran poros. Putaran poros tersebut kemudian digunakan untuk beberapa hal sesuai dengan kebutuhan seperti memutar dinamo atau generator untuk menghasilkan listrik. Desain dari kincir/turbin angin sangat banyak macam jenisnya, berdasarkan bentuk rotor, kincir angin dibagi menjadi dua tipe, yaitu Turbin Angin Sumbu Mendatar (Horizontal Axis Wind Turbine) dan Turbin Angin Sumbu Vertikal (Vertical Axis Wind Turbine) (Daryanto, 2007).

Untuk membangun suatu unit pembangkit listrik tenaga angin banyak faktor yang harus dipertimbangkan antara lain data kecepatan angin pada lokasi atau daerah yang memungkinkan untuk dibangun PLT-Angin, untuk keperluan apa pembangkit itu dibangun dan bentuk dari pembangkit tersebut (Endang Wachyan, 2001; Fitri Imansyah, 2002).

Tenaga angin sangat berpengaruh terhadap fluktuasi dan arah angin yang ditentukan oleh keadaan perubahan alam dan sekelilingnya, jadi sangat diperlukan survei data angin pada lokasi yang akan dibangun Sistem Instalasi Pembangkit Listrik Tenaga Angin (SIPLT-Angin) agar memberikan keandalan yang lebih optimal, baik untuk pembangkit yang berskala kecil 
maupun besar dengan parameter sebagai berikut: (a) kecepatan rata-rata harian, bulanan dan tahunan; (b) kecepatan angin maksimum dan (c) perubahan arah angin.

Pembangunan PLT-Angin harus memperhatikan beberapa faktor antara lain: (1) dibangun pada lokasi yang memiliki kecepatan angin rata-rata yang cukup tinggi; (2) letak atau lokasi pembangunan SIPLT-Angin terhadap kontur permukaan bumi, sebaiknya dibangun pada kontur yang paling tinggi pada puncak bukit atau gunung hal ini untuk mengurangi adanya hambatan pada angin sehingga angin memiliki tekanan yang kuat; (3) pada dataran terbuka yang tidak memiliki rintangan seperti padang pasir, pantai atau permukaan laut, dan pada lembah gunung yang berbentuk corong (Jhonni MTS, 1996).

Kincir angin atau turbin angin mengubah energi kinetik angin ke kerja mekanis. Untuk memproduksi listrik, sistem ini didesain untuk selalu beroperasi pada kecepatan sudut yang tetap dengan kecepatan angin yang berubah-ubah. Ada bermacam-macam kincir angin, termasuk turbin propeller dan lain-lain turbin aliran aksial, juga sistem radial yang dipasang pada sumbu tegak.

Perencanaan unjuk kerja kincir angin sumbu horizontal tipe multiblade dengan 8 sudu diperlukan untuk menjaga agar perbandingan daya dan berat sekecil mungkin. Ini mengurangi tegangan yang diakibatkan oleh gaya sentrifugal sudut (M. Iqbal Arsyad, 2001). Secara teori jumlah daya yang biasa diserap oleh kincir angin adalah $59 \%$ untuk turbin dengan cerobong dan untuk turbin terbuka kira-kira 50-70 \% dari harga ini karena adanya kebocoran dan efekefek lain (Harijono Djojodiharjo, 1983).

Daya yang dihasilkan oleh kincir angin secara langsung tergantung dari luas daerah yang disapu oleh sudu dan daya angin per satuan luas yang tegak lurus pada kecepatan angin sebanding dengan kecepatan angin pangkat tiga (Y, Ismail 1998, 2000, 2003).

Jika sistem direncanakan untuk memproduksi listrik bolak balik (AC), dibutuhkan gaya dan kecepatan sudut yang konstan. Sayang sekali, kecepatan angin tidaklah konstan, baik dalam arah maupun besarnya dan juga bervariasi pada bagian bawah dan atas sayap yang berukuran besar, ini menyebabkan terjadinya beban siklus yang berat pada sayap turbin yang menyebabkan masalah kelelahan (fatique) (Harijono Djojodiharjo, 1983).

Kincir angin/turbin angin, memiliki beberapa bagian yang berhubungan, terdiri dari kipas (baling-baling), poros bantalan, gear, generator DC, dimana tenaga yang diberikan dari angin tersebut memutar kipas pada kincir. Perputaran kipas tersebut diikuti proses pengkopelan yang menyebabkan berputarnya poros dan kemudian dihubungkan lagi ke generator DC yang menghasilkan tenaga listrik yang akan disimpan dalam akumulator (baterai).

Untuk mendapatkan tenaga listrik menggunakan kincir angin terdapat permasalahan utama, yaitu bagaimana merancang sebuah kincir angina mengunakan material lokal. Perlu diperhitungkan rugi-rugi energi dari sistem yang dirancang: (1) akibat gesekan udara dan pergerakan udara yang bergantung pada bentuk dan rakitan sayap. Semua kerugian itu dimasukkan ke dalam rendemen aerodinamik, dan berkisar antara 0,3 dan 0,8; (2) akibat gesekan bantalan yang bergantung pada rakitan bantalan, beban bantalan dan pelumasan. Semua itu dimaksudkan ke dalam rendemen mekanik, yang pada perakitan yang tepat tidak perlu lebih rendah daripada 0,9; (3) kerugian elektro-mekanik, bila energi angin diubah menjadi energi listrik. Semua kerugian itu dimasukkan ke dalam rendemen dynamo $\pm 0,5$.

Permasalahan paling pokok dalam Pengabdian Kepada Masyarakat ini adalah banyaknya nelayan yang menggunakan lampu penerangan bagan menggunakan petromaks (lampu minyak) dan lampu DC (baterai/accu). Kelemahan menggunakan accu (lampu DC) adalah daya tahan penyimpanan energi dalam accu tersebut, biasanya dapat digunakan 1 sampai 2 malam, setelah itu energi dalam accu habis. Agar lampu DC dapat menyala kembali 
maka accu harus dibawa ke darat untuk dilakukan isi ulang (charging). Kegiatan rutin ini sangatlah merepotkan para nelayan. Di lain sisi, pada malam hari, tempat para nelayan memasang bagan, kecepatan angin di laut sangatlah kencang. Kondisi inilah yang dimanfaatkan untuk membangkitkan energi listrik yang dapat digunakan langsung untuk penerangan sekaligus untuk penyimpanan energi dalam accu, sehingga nelayan tidak perlu ke darat untuk melakukan charging accu.

Selanjutnya untuk mendapatkan tenaga listrik yang kita inginkan dengan menggunakan kincir angin terdapat permasalahan yang dihadapi, yaitu bagaimana kita merencanakan komponen-komponen dari kincir angin tersebut. Seperti poros dan gear serta kerangkanya agar kincir angin tersebut dapat bekerja menghasilkan tenaga listrik yang sesuai dengan diinginkan.

Dengan kondisi tersebut maka perlu dikembangkan suatu fasilitas yang menghubungkan (mendukung) dengan target biaya perbaikan, biaya perawatan, keunggulan peralatan dan ketahanan peralatan dalam perumusan. Dengan permasahan di atas maka dibuatlah suatu contoh pembangkit listrik tenaga angin laut sebagai sumber energi alternatif untuk kebutuhan nelayan guna meningkatkan kapasitas ikan tangkapan.

Kegiatan yang dilaksanakan oleh tim ini merupakan salah satu Tri Dharma Perguruan Tinggi yaitu Pengabdian kepada Masyarakat yang turut serta berperan mengkaji dan memecahkan masalah yang berkembang di masyarakat dalam hal ini nelayan. Secara umum kegiatan ini bertujuan agar:

1. Membantu meningkatkan kemampuan SDM, melalui latihan yang dikembangkan secara sistematik dan berkelanjutan di bidang rancang bangun mesin pembangkit listrik tenaga angin serta peningkatan hasil tangkapan ikan nelayan.

2. Mengembangkan industri kecil dan kemampuan rancang bangun dan kerekayasaan serta meningkatkan human resources.

3. Menimbulkan proses transformasi budaya yang positif, dari budaya tradisional menuju budaya modern.

4. Terlatihnya 25 orang nelayan dalam hal pengembangan desain mesin pembangkit listrik tenaga angin skala kecil.

5. Mengubah pola pikir 25 orang nelayan dalam pengembangan usaha penangkapan ikan dari satu proses penangkapan menjadi aneka proses penangkapan ikan.

\section{Metodologi}

Metode kegiatan yang dilakukan dalam pengembangan teknologi pembangkit listrik tenaga angin untuk nelayan guna meningkatkan kapasitas ikan tangkapan adalah sebagai berikut:

\section{A. Research and Information Collection}

Penelitian dan pengumpulan data. Termasuk analisis kebutuhan, studi literatur dan observasi lapangan.

\section{B. Planning (Perencanaan)}

Pada tahap perencanaan ini, peneliti mulai menetapkan rancangan perangkat (alat dan bahan), rancangan model, untuk memecahkan masalah yang telah ditemukan pada tahap pertama. 


\section{Preliminary Form of Product (Pengembangan Produk Awal)}

Tahap ini mempersiapkan perangkat kerja pembuatan sistem alat dan kegiatan perekayasaan atas penerapan peluang-peluang penghematan energi.

\section{Preliminary Field Testing (Uji Lapangan Produk Awal)}

Setelah model dan perangkatnya siap untuk digunakan, kegiatan selanjutnya adalah melakukan uji coba dilapangan. Data yang diperoleh kemudian dianalisis dan dievaluasi untuk memperbaiki penerapan model pada tahap berikutnya.

\section{E. Main Product Revision (Revisi Hasil Ujicoba)}

Memperbaiki atau menyempurnakan hasil ujicoba berdasarkan masukan dari hasil ujicoba produk awal, dengan menganalisis kekurangan yang ditemui selama uji coba di lapangan, dan mempertimbangkan hasil evaluasi teman sejawat, hasil evaluasi ahli media dan ahli materi.

\section{F. Main Field Testing (Uji lapangan)}

Produk yang diperbaiki berdasarkan uji coba lapangan, kemudian diujicobakan pada tempat yang sesungguhnya yaitu di pantai pulau temajo.

\section{G. Operational Produk Revision (Revisi Produk)}

Menyempurnakan produk hasil uji lapangan berdasarkan masukan hasil uji sesungguhnya yaitu di pantai pulau temajo.

\section{H. Operational Field Testing (Uji lapangan)}

Pengujian kesemua sistem bekerja dengan baik dengan melihat kinerja putaran balingbaling, pengisian daya pada accu dan penyalaan lampu. Selanjutnya dilakukan monitoring atau pengawasan adalah suatu proses yang merupakan bagian dari manajemen energi yang berupa pemantauan segala aktifitas yang berkaitan dengan pemakaian energi dan indikasi penyimpangan energi dari hasil implementasi yang kemudian dijadikan bahan input untuk laporan energi.

\section{Final Product Revision (Revisi Produk Akhir)}

Sebelum model dipublikasikan ke sasaran pengguna, maka perlu dilakukan revisi terakhir untuk menyempurnakan model berdasarkan hasil analisis data pada uji lapangan terakhir. Langkah ini meliputi: uji laik operasi pembangkit adalah kegiatan pemeriksaan dan penyaksian pengujian pembangkit listrik dalam rangka pemenuhan persyaratan kelaikan operasi; kajian dampak lingkungan adalah kegiatan penelitian dampak lingkungan akibat rencana pengembangan/pembangunan/modifikasi suatu instalasi/area/bangunan.

\section{J. Disemination and Implementasi}

Melaporkan produk akhir hasil kegiatan dan pengembangan.

Rancang bangun PLT-Angin ini dilakukan melalui beberapa langkah; (a) Perancangan peralatan teknis seperti turbin, kontrol turbin, rangka, instalasi dan lain-lain, (b) Pengerjaan konstruksi tiang penopang turbin; (c) Pengerjaan jaringan sambungan aliran ke rumah pengecasan akumulator. Prototipe PLT-Angin ini dirancang dengan sistem bongkar pasang yang artinya hampir semua komponennya dapat dipisahkan dengan mudah dan dalam pemasangan hanya menggunakan baut tanpa dilas atau dengan paku keling, sehingga hal ini 
dapat mempermudah dalam proses pembuatan dan perakitan. Berikut adalah diagram blok yang menggambarkan metode perencanan dan sistem kerja serta aplikasi dilapangan dari sebuah sistem PLT-Angin.
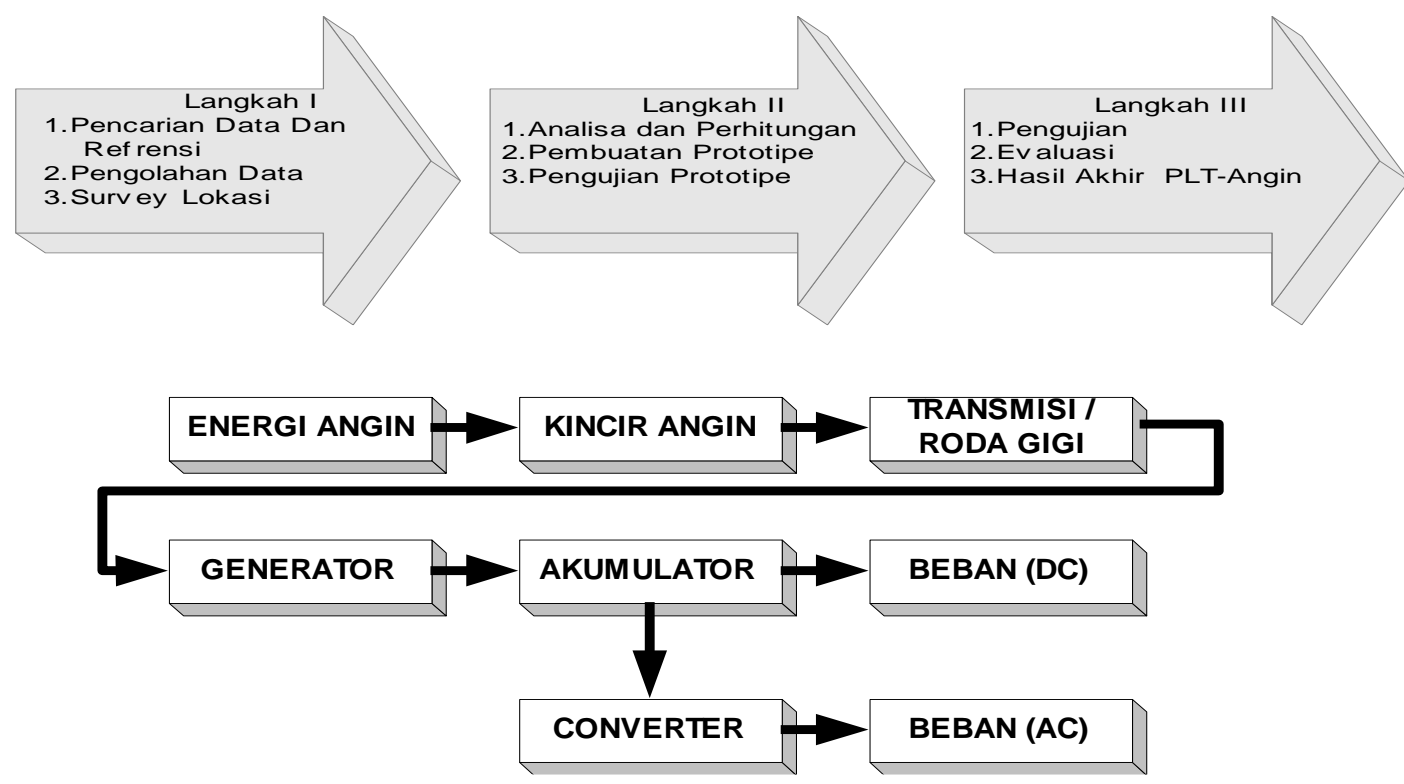

Gambar 1. Diagram Blok Metode Perencanaan Kincir Dan Diagram Blok Sistem PLT-Angin
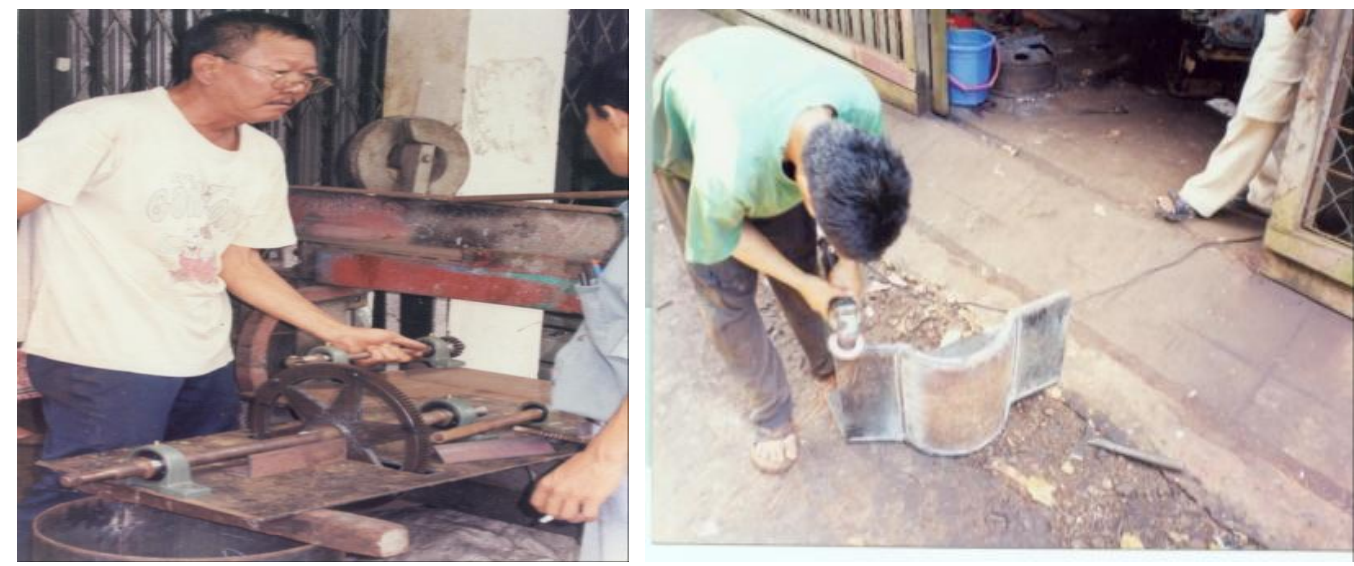

Gambar 2. Proses Pembuatan Pembangkit Listrik Tenaga Angin 

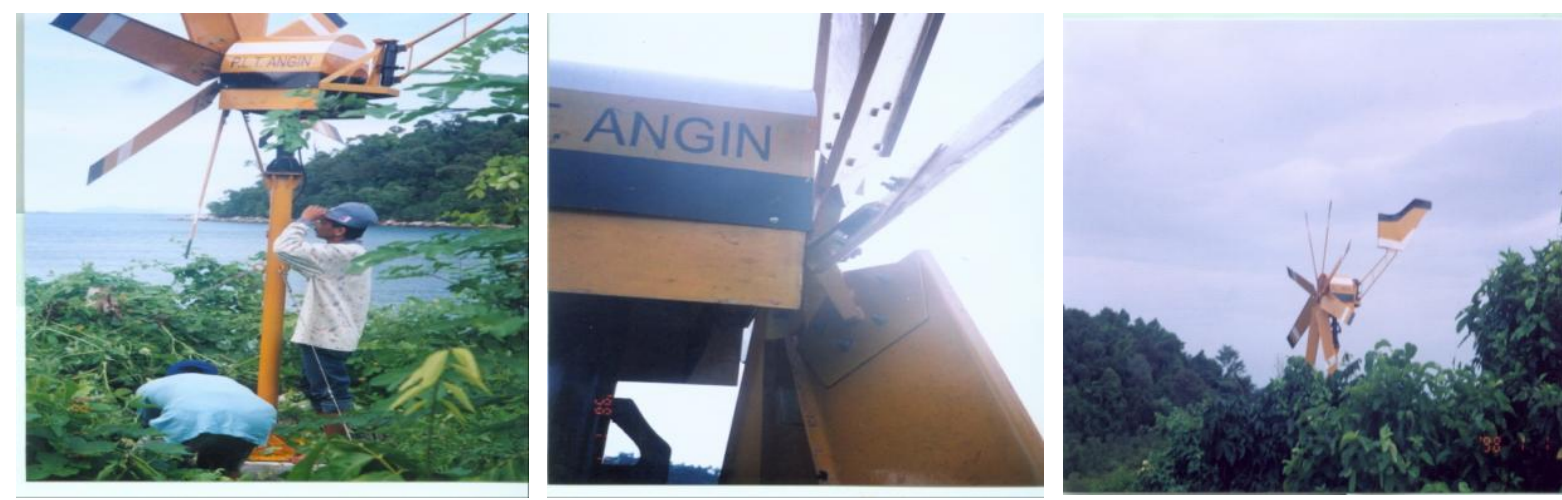

Gambar 3. Peletakan Pembangkit Listrik Tenaga Angin
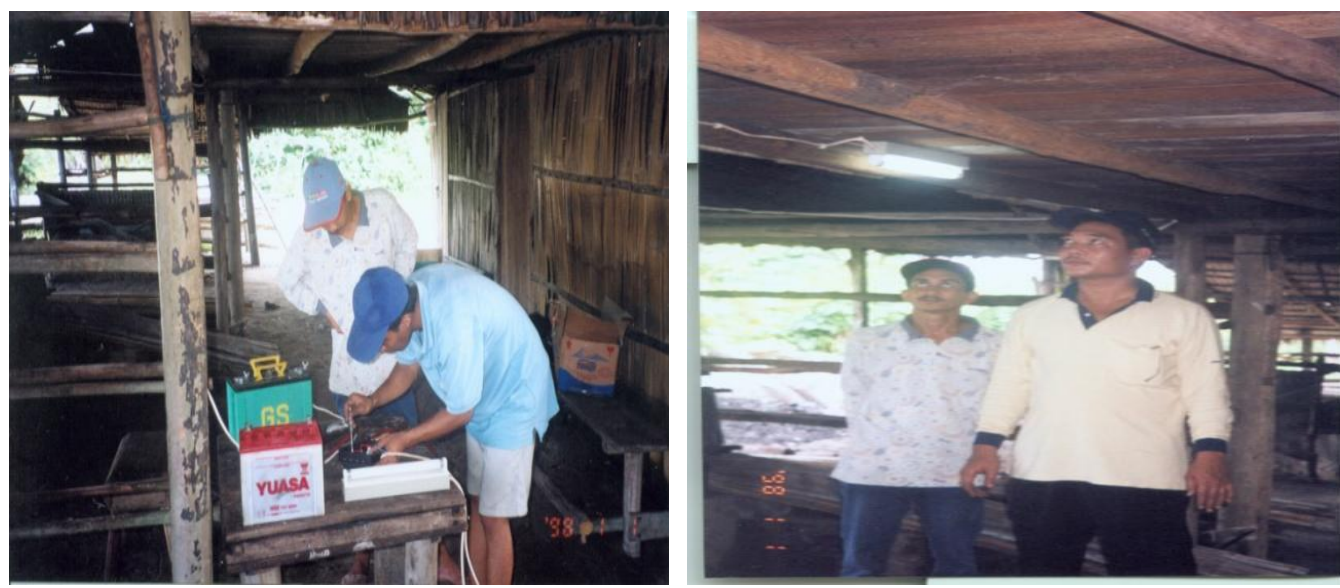

Gambar 4. Uji Coba Pengisian Penyimpanan Daya Dalam Akumulator yang Dapat dimanfaatkan Oleh Nelayan

Setelah dilakukan pemasangan, nelayan di lokasi tersebut juga diberikan pelatihan tentang perawatan alat PLT-Angin tersebut agar dapat menambah wawasan. Dengan mengetahui permasalahan di atas perlu diupayakan langkah-langkah pemecahan. Langkahlangkah tersebut antara lain memberikan pemahaman kepada masyarakat khususnya nelayan tentang upaya peningkatan kapasitas ikan tangkapan di bagan/kelong yang mereka punyai. Pelaksanaan kegiatan PKM ini diikuti oleh 25 orang peserta yang terdiri atas para nelayan di Desa Sungai Kunyit Kabupaten Mempawah. Dengan diberikannya ceramah dan tanya jawab serta kegiatan workshop ini diharapkan para nelayan pada khususnya akan menyerap informasi yang diberikan perguruan tinggi dan mampu menyebarkannya kepada masyarakat yang lainnya baik itu dalam kawasan maupun kawasan lainnya. Karena keterampilan dapat diperoleh melalui pelatihan baik secara teori maupun praktik di lapangan. Sehingga jika terjadi kerusakan maka para nelayan tersebut dapat memperbaikinya sendiri.

\section{Hasil dan Pembahasan}

Jenis kincir yang dipergunakan pada prototype PLT-Angin ini adalah jenis kincir dengan konstruksi yang mudah dan ekonomis dengan spesifikasi: (1) tipe sejajar dengan arah angin (sumbu horizontal), dengan 8 sudu; (2) bentuk sudu persegi panjang (rectangular); (3) bahan yang dipergunakan adalah plat besi dengan ketebalan $1 \mathrm{~mm}$. 
Dalam melakukan pengujian panel kontrol dan generator digunakan motor DC untuk mendapatkan putaran simulasinya (Sahat Pakpahan, 1994). Selain itu pada PLT- Angin yang sebenarnya digunakan sistem roda gigi sebanyak 3 tingkat guna memperoleh putaran generator yang cukup untuk menghasilkan arus listrik. Meskipun pada pengujian di laboratorium tidak menggunakan roda gigi bertingkat, sedangkan generator tidak dapat diubah-ubah kecepatannya, maka untuk mendapatkan putaran generator seperti yang diinginkan, generator dikopel secara langsung ke motor DC dan selanjutnya pengaturan dilakukan pada motor DC sesuai dengan besarnya kecepatan yang diinginkan berdasarkan hasil perhitungan dari data hasil pengukuran di lokasi penempatan PLT-Angin.

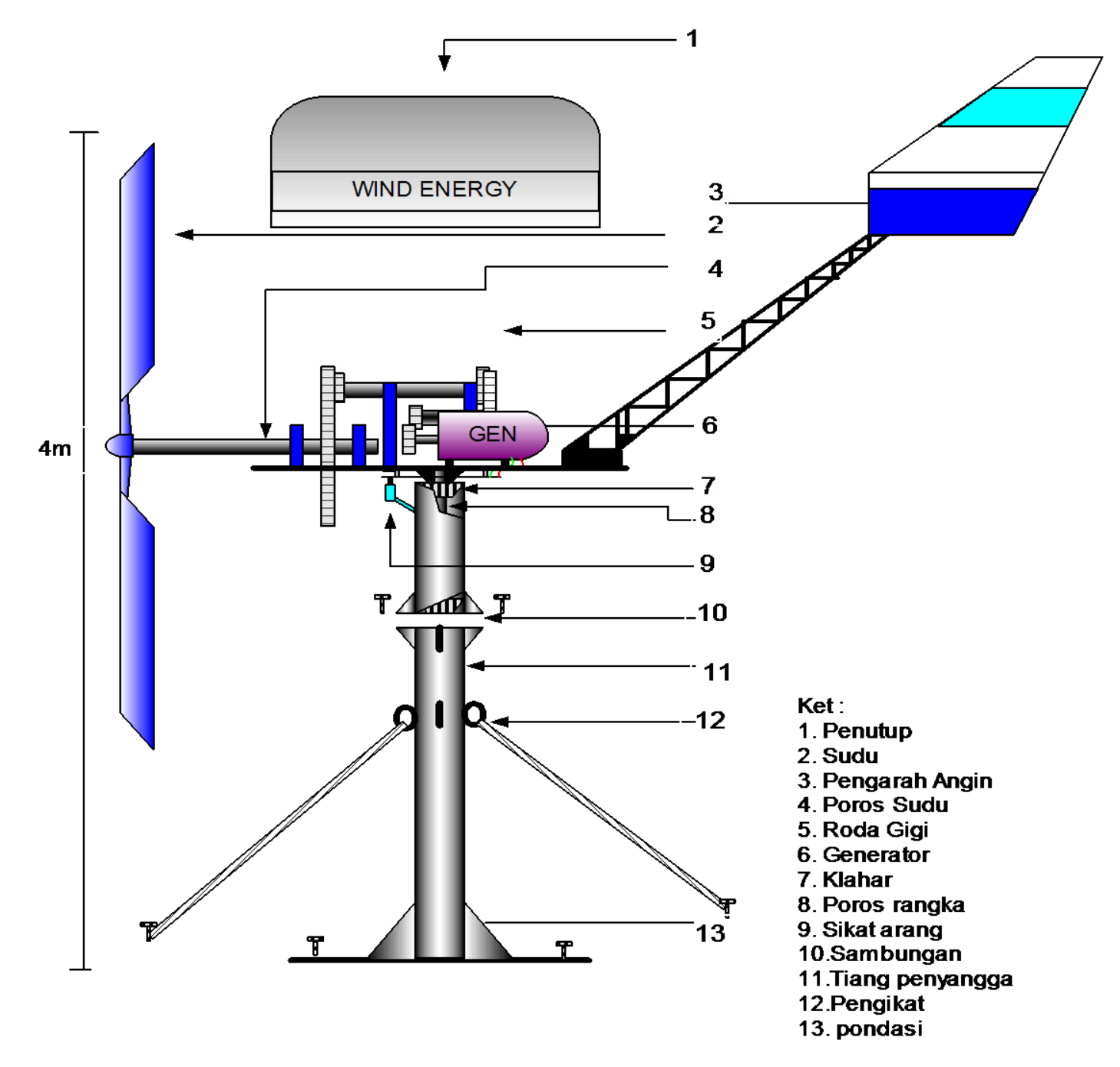

Gambar 5. Prototipe PLT-Angin Dengan Jenis Kincir Sumbu Horizontal Tipe Multiblade 8 Sudu

Kecepatan angin berbanding lurus dengan putaran kincir dan putaran generator hal ini berarti bahwa semakin kencang angin bertiup maka akan semakin tinggi pula kecepatan putar pada kincir dan generator, sedangkan perbedaan yang terjadi antara hasil analisa perhitungan dan hasil pengujian disebabkan beberapa hal antara lain: (1) ketelitian dalam pembacaan instrumen ukur; (2) adanya rendemen dari seluruh peralatan dari PLT-Angin tersebut ; (3) efisiensi dari peralatan tersebut yang masih rendah. Daya listrik yang dihasilkan dari PLTAngin ini sangat dipengaruhi oleh rugi-rugi dan efisiensi dari peralatan karena apabila rugi- 
rugi pada peralatan tersebut sangat besar maka daya yang akan dihasilkan menjadi semakin kecil, hal ini akan membuat peralatan menjadi tidak efisien.

Beberapa komponen PLT-Angin yang harus mendapat perhatian khusus agar PLTAngin tersebut dapat bekerja dengan baik adalah : (1) apabila dalam perancangan sudu dan rangka sudu terdapat kesalahan, seperti pemilihan bahan sudu yang tidak sesuai (bahan sudu sangat berat dan tidak memiliki sifat aerodinamis yang tinggi atau bahan sudu tersebut tidak memiliki kekuatan), maka akan memperlambat putaran dari kincir tersebut ; (2) rangka sudu haruslah kuat dan dapat berputar pada porosnya dengan seimbang dan sempurna agar kincir dapat berputar dengan kecepatan tinggi walaupun pada kecepatan angin rendah ; (3) pemilihan sistem transmisi yang tepat pada PLT-Angin ditujukan untuk mengurangi banyaknya atau beratnya gesekan pada setiap poros roda gigi, maka digunakan bantalan, tata letak roda gigi yang sangat mempengaruhi efisiensi dari sistem transmisi tersebut; (4) generator yang dipergunakan harus sesuai dengan kapasitas dari pembangkit karena apabila kapasitas generator melebihi dari kemampuan PLT-Angin tersebut maka kincir tidak akan dapat memutar generator, karena dengan kapasitas generator yang besar berarti memerlukan torsi awal yang besar pula, hal ini akan mengakibatkan semakin besarnya energi yang terbuang.

Kegiatan pengabdian ini merupakan hilirisasi teknologi dari hasil-hasil penelitian. Karena itu apa yang dilaksanakan dalam kegiatan PKM yang sangat dibutuhkan oleh masyarakat nelayan dipesisir pantai, merupakan penerapan berbagai ipteks yang sudah teruji dalam tataran penelitian/uji coba yang di desiminasikan melalui ke masyarakat pengguna melalui kegiatan PKM.
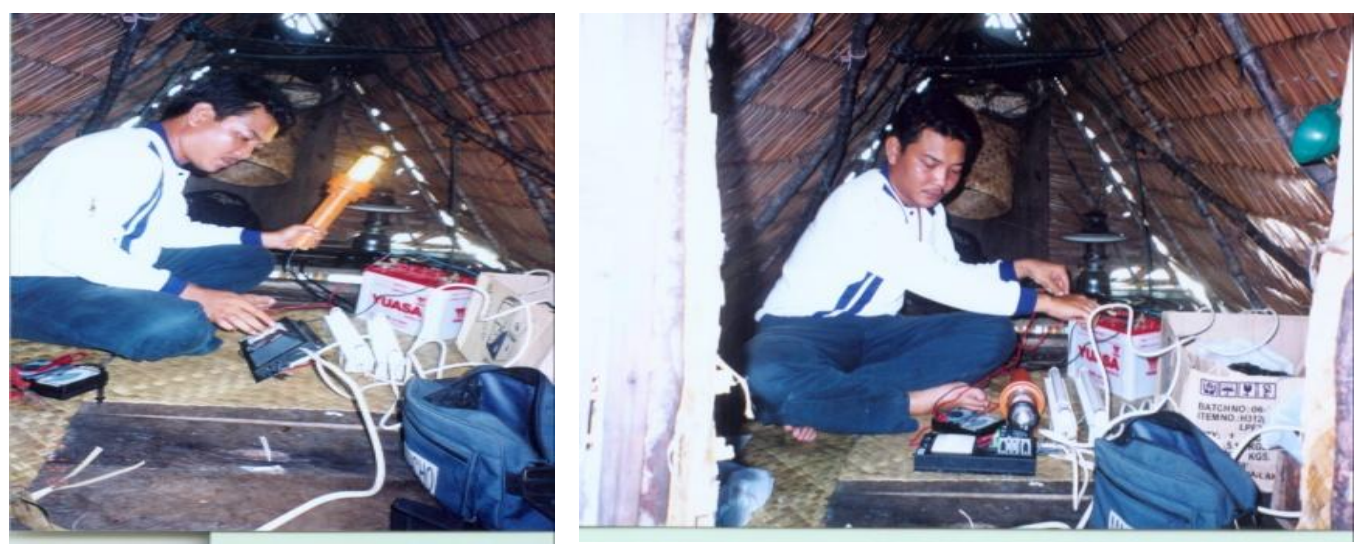

Gambar 6. Penerapan Hasil Pengisian Penyimpanan Daya

Dalam Akumulator yang Dapat Dimanfaatkan Oleh Nelayan

Selanjutnya kegiatan berupa tatap muka dan workshop yang dilakukan selama satu hari dimulai dari tanggal 24 November 2020, jam 09.00 sampai 14.00 WIB diantara waktu tersebut diselingi dengan coffee break dan istirahat makan siang. Pelaksanaan kegiatan ini diselenggarakan di Balai Desa Sungai Kunyit Kabupaten Mempawah. Materi yang disampaikan meliputi:

1. Proses Rancang Bangun Dan Pembuatan Mesin Pembangkit Listrik Tenaga Angin Skala Kecil.

2. Operasional Dan Pemeliharaan Mekanisasi Mesin Pembangkit Listrik Tenaga Angin.

3. Operasional dan Pemeliharaan penyaluran listrik terkontrol dan proses penyimpanan dalam akumulator. 

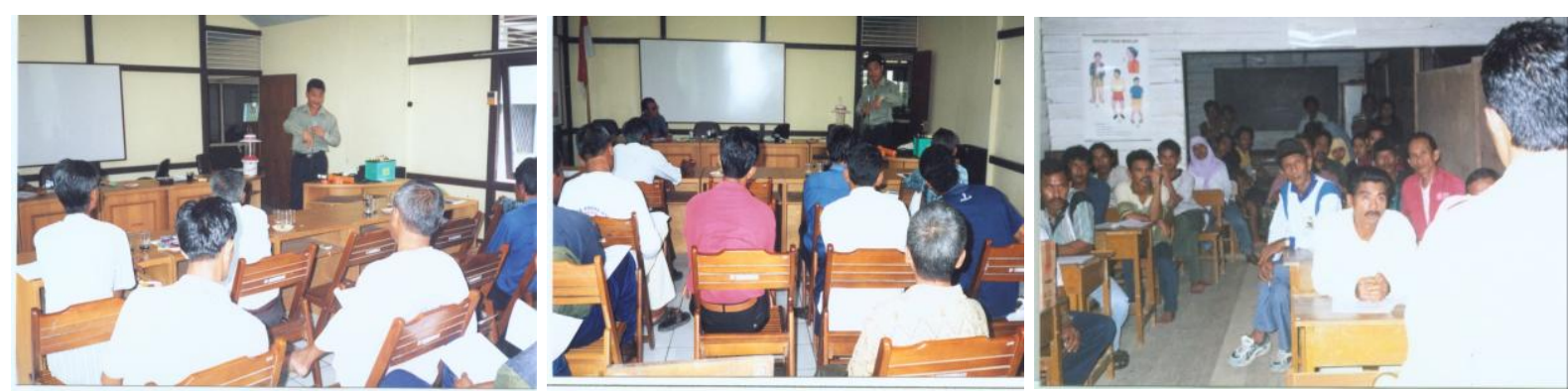

Gambar 7. Sosialisasi Penerapan Pembangkit Listrik Tenaga Angin dan Proses Pengisian Penyimpanan Daya Dalam Akumulator

Dari kegiatan ceramah/diskusi dan kegiatan workshop perlu kiranya mengevaluasi kembali pada para nelayan yang diberikan materi apakah dapat memotivasi nelayan untuk melanjutkan atau menerapkannya dalam kehidupannya untuk menangkap ikan, apabila ada masalah secara teknis maka pihak perguruan tinggi akan membantu sehingga ada saling keterkaitan antara pihak-pihak yang berkepentingan dan nelayan dengan pihak perguruan tinggi. Evaluasi kegiatan Pengabdian Kepada Masyarakat ini dilakukan setelah metode tanya jawab dilaksanakan dari perencanaan pada waktu pelaksanaan dan setelah kegiatan berakhir dilakukan kegiatan workshop dengan harapan agar tidak terjadi penyimpangan dari tinjauan semula.

Hasil lainnya dari kegiatan sosialisasi dan workshop ini adalah:

1. Evaluasi ini dilakukan untuk mengukur keluaran pembangkit listrik tenaga angin dan menilai tingkat pencapaian keberhasilan dan manfaat pembangunan pembangkit listrik tenaga angin yang dirasakan oleh masyarakat nelayan di daerah Sungai Kunyit Kabupaten Mempawah tersebut. Bentuk evaluasi yang dilakukan adalah mengamati hasil pengukuran keluaran generator dan lama waktu penggunaan listrik yang tersimpan di bateray/accu. Dengan terpasangnya PLT-Angin ini masyarakat dapat mengenal dan memanfaatkan teknologi energi alternative untuk penerangan pada lokasi bagan nelayan. Pelatihan yang diberikan kepada nelayan agar dapat dilakukan perawatan sendiri untuk menjaga umur pakai alat dan keamanan bagi yang melakukan perawatan. Keamanan bagi manusia berarti harus aman bagi orang yang memasang, mengoperasikan dan yang merawat atau memperbaikinya karena arus listrik sangat berbahaya. Sebagai sumber energi, listrik harus digunakan tanpa banyak menimbulkan bahaya. Setiap orang yang menggunakan dan bekerja pada bidang listrik harus memperhatikan hal-hal yang berkaitan dengan keamanan terutama terhadap arus kejut. Jika terjadi kontak dengan tegangan, aliran arus akan melalui tubuh dan menghasilkan kejutan listrik yang meyebabkan tubuh kita terbakar dan luka serius, bahkan dapat menyebabkan kematian.

2. Sebelum pengoperasian mesin perlu diperhatikan apakah ikatan baut dan mur sudah kencang, karena saat mesin beroperasi bebannya cukup besar. Pemasangan mesin perlu dengan pengikatan yang baik dan perlu peredam getaran agar tetap stabil.

3. Dalam membuat tower untuk peletakan mesin pembangkit perlu diusahakan kekuatan tower yang kuat dan kokoh, bila perlu menggunakan besi. Dalam menjalankan mesin terutama terhadap bahaya gerakan baling-baling perlu memperhatikan dan menjaga faktor keselamatan kerja. 
4. Sebaiknya dibuat jadwal perawatan pada kincir angin terebut dengan baik dan terencana, agar kondisi dan kerja dari kincir tersebut dapat sesuai dengan apa yang kita inginkan.

5. Kincir angin dapat bekerja dengan baik dan efektif apabila dalam penempatannya sesuai dengan daerah dengan hembusan angin yang cukup kencang, misalnya daerah pantai dan daerah pegunungan.

6. Kegiatan ini disamping menunjang program Pemerintah di bidang perikanan dan Dikti lewat program SIBERMAS (Sinergi Pemberdayaan Potensi Masyarakat) khususnya peningkatan produktivitas perikanan juga memanfaatkan bahan lokal yang sudah tersedia sehingga diharapkan dalam waktu tertentu dapat meningkatkan baik segi jumlah maupun produktivitas masing-masing nelayan, dengan demikian program pemerintah mengenai ikan murah dapat tercapai.

7. Berdasarkan simpulan yang didapatdari kegiatan workshop, maka disarankan : Pertama, desain dari sudu sangat berpengaruh pada energi yang dihasilkan, karena apabila sudu memiliki efesiensi aerodinamis yang tinggi maka energi yang dihasilkan dari sudu ini akan jauh lebih besar dari pada energi yang dihasilkan sudu yang memiliki efesiensi aerodinamis yang rendah, untuk itu rangka kincir harus memiliki keseimbangan yang baik (balance) agar sudu dapat berputar dengan maksimal dan mengurangi getaran yang ditimbulkan kincir, Kedua, tata letak roda gigi dari sistem transmisi haruslah tepat dan benar untuk memperkecil energi yang hilang, Ketiga, pemilihan turbin angin yang sesuai pada suatu daerah harus mempertimbangkan kecepatan angin rata-rata daerah tersebut, kecepatan angin maksimum dan perubahan arah angin yang diproyeksikan pada pusat ketinggian turbin serta karakteristik turbin angin.

8. Untuk meningkatkan kesadaran masyarakat tentang mesin pembangkit listrik tenaga angin skala kecil dalam upaya peningkatan kapasitas ikan tangkapan serta bagaimana proses pembuatannya perlu sosialisasi kepada nelayan di beberapa tempat lainnya agar dapat meningkatkan produktivitas di wilayah mereka masing-masing.

\section{Simpulan}

Dalam memanfaatkan teknologi tepat guna berupa pembangkit listrik tenaga angin skala kecil diharapkan dapat mewujudkan modernisasi usaha perikanan yang diikuti alokasi sarana dan prasarana yang diperlukan agar nelayan mampu mengembangkan usahanya sebagai usaha yang tangguh dan memiliki daya saing yang kuat, serta meningkatkan produktivitas dan modernisasi usaha sehingga dicapai perbaikan sistem pengembangan usaha perikanan serta pengolahan dan pemanfaatan sumber daya alam yang ada di lokasi usaha perikanan agar ketersediaan ikan selalu terpenuhi. Program pengabdian kepada masyarakat ini bertujuan untuk membangun pembangkit listrik tenaga angina (PLT-Angin) sebagai sumber energi alternative terbarukan dengan menggunakan turbin angin sumbu horizontal tipe multiblade 8 sudu. Selanjutnya energi tersebut dapat disimpan untuk dimanfaatkan nelayan mencharger accu yang dapat dibawa ke bagan nelayan mereka untuk dapat disambungkan ke lampu. Pembangkit listrik tenaga angin sumbu horizontal untuk nelayan guna meningkatkan kapasitas ikan tangkapan dapat diterapkan kembangkan di daerah pesisir pantai yang belum terjangkau jaringan listrik dari PLN. 


\section{Ucapan Terima Kasih}

Pelaksana mengucapkan terima kasih kepada BAPPEDA, Dinas Kelautan Dan Perikanan, kelompok masyarakat sasaran PKM Kabupaten Mempawah yang telah membantu pelaksanaan kegiatan pengabdian masyarakat ini beserta seluruh pihak yang tidak bisa penulis sebutkan satu persatu.

\section{Daftar Pustaka}

Endang Wachyan, Teguh Pamungkas, 2001, Penerapan Kincir Angin Untuk Irigasi Pedesaan Didaerah Pemukiman Nelayan, Cirebon: Departemen Pemukiman Dan Prasarana Wilayah - BALITBANG KIMPRASWIL

Fitri Imansyah, 2002, Pembangkit Listrik Tenaga Angin Sebagai Sumber Energi Terbarukan Untuk Kebutuhan Penerangan Bagan Nelayan, Pontianak: BALITBANGDA KALBAR.

Guntoro, W., 2008. Studi Pengaruh Panjang dan Jumlah Baling-Baling Terhadap Efisiensi Daya Listrik Pada Pembangkit Listrik Tenaga Angin. Bandung:ITB

Harijono Djojodiharjo, Jens Peter Molly, 1983, Wind Energy Sistem, Bandung: Penerbit Alumni.

Jhonny MTS, 1996, Pengenalan Energi Angin Pengukuran kecepatan Angin Dan Distribusi Kecepatan Angin, Modul Pelatihan Bimbingan Teknik Bina Usaha Energi Baru, Pontianak: LPKM Untan.

M. Iqbal Arsyad, Fitri Imansyah, 2001, Perancangan Unjuk Kerja Prime Mover Turbin Pembangkit Listrik Tenaga Angin Sebagai Sumber Energi Alternatif Untuk Kebutuhan Nelayan, Pontianak: Lemlit UNTAN.

Sahat Pakpahan, 1994, Instrumentasi Elektronik Dan Teknik Pengukuran, Jakarta: Ciracas.

Y. Ismail, Y. Kemmoku, D. Martin, T. Sakakibara, 1998 "Analysis of Insolation and Wind Speed in Indonesia" Tokai-Section Joint Conference of The Seven Institutes of Electrical and Related Engineers, Mie - Japan

Y. Ismail, Y. Kemmoku, D. Martin, T. Sakakibara, 2000 "A Method of Diesel/Wind/Battery Hybrid Power System" Tokai-Section Joint Conference of The Seven Institutes of Electrical and Related Engineers, Hammamatsu - Japan

Y. Ismail, Y. Kemmoku, H. Takikawa, T. Sakakibara, 2003 "Variable Charge Level Operating Method for A Stand Alone Photovoltaic/Wind/Diesel/Battery Hybrid Power System", Journal of Japan Solar Energy Society, Vol. 29, No. 3, pp. 45-53, 